\title{
Starter cultures used in probiotic dairy product preparation and popular probiotic dairy drinks
}

\author{
Oktay YERLIKAYA ${ }^{1 *}$
}

\begin{abstract}
Dairy products that contain probiotic bacteria are those that are produced with various fermentation methods, especially lactic acid fermentation, by using starter cultures and those that have various textures and aromas. Fermented dairy products are popular due to their differences in taste and their favourable physiological effects. Today, fermented dairy beverages in general are produced locally by using traditional methods. Recently, due to the increased demand for natural nutrients and probiotic products, fermented dairy beverages have reached a different position and are considered to have an important impact on human health and nutrition. In this article, probiotic bacteria and functional dairy products that are produced by using probiotic bacteria are discussed.
\end{abstract}

Keywords: probiotics; fermented dairy products; lactic acid bacteria; dairy drinks.

\section{Introduction}

Fermented dairy products are products that can be produced via fermentation of lactose by microorganisms especially by lactic acid bacteria. When examining worldwide, various dairy products which are different in name but similar in content can be found and those products are an important part of human diet (Tamime \& Marshall, 1997; Moayednia et al., 1999; Tamime \& Robinson, 1999; Nilsson et al., 2006; Hugenholtz, 2013). Fermented dairy products in question are usually produced by using lactic acid bacteria and yeasts (Ozer \& Kirmaci, 2010). Fermented dairy products that are produced with different fermentation types are shown in Table 1.

Probiotics are defined as living microorganisms, which when ingested in sufficient amounts, beneficially influence the health of the host by improving the composition of intestinal microflora. In addition to improving gut health, probiotics may play a beneficial role in several medical conditions, including lactose intolerance, cancer, allergies, hepatic disease, Helicobacter pylori infections, urinary tract infections, hyperlipidemia and assimilation of cholesterol (Ejtahed et al., 2011). Probiotic microorganisms that are known to be beneficial to human health can be ingested through fermented dairy products, enrichment of various foods with these bacteria and consumption of pharmaceutical products that are obtained by using viable cells (lyophiled preparations and tablets). Probiotics are defined as viable microorganisms which can be consumed separately or with foods, which assist dietary and microbial balance by regulating the mucosal and systemical immunity and beneficially affect the consumer's health. A great variety of dairy products contain probiotic bacteria (Ziemer \& Gibson, 1998; Moayednia et al., 1999; Salminen et al., 1999; Gibson \& Fuller, 2000; Granato et al., 2010; Guldas \& Irkin, 2010; Kanmani et al., 2013; Lollo et al., 2013).

Probiotic foods enhance health after consumption and contains microorganisms which are viable, specific and effective on main systems of nutritional physiology. In Japan, probiotics are consumed as frozen culture tablets whilst in Europe, due to the bias against medication, probiotics are only consumed through the inclusion of probiotics to foods (Vaughan \& Mollet, 1999; Shah, 2001; Soccoll et al., 2010).

Fermented milks have long been used as the main vehicles for probiotic strains. Less frequently, cheeses have been used for incorporation of probiotic microorganisms, but they may offer a number of advantages compared with fermented milks (Gomes et al., 2011; Minervini et al., 2012). Cheese has higher $\mathrm{pH}$, more solid consistency, and relatively higher fat content compared with fermented milks such as yoghurt (Karimi et al., 2012).

\section{Selecting probiotic strains for probiotic dairy products}

Probiotic dairy products have favourable effects on human health such as, reducing lactose intolerance, prevention of diarrhea and constipation, increase in the effectiveness against Helicobacter pylori infection, preservation of oral health, partial prevention of cancer, cholesterol lowering, enhancement of mineral absorbtion. Along with their extensive effects on human health, they have the ability to form low molecular weight components such as conjugated linoleic acid (CLA), gamma aminobutyric acid (GABA) and bacteriocin (Gobbetti et al., 2010; Šušković et al., 2010; Divya et al., 2012; Kanmani et al., 2013).

Several factors must be considered when using probiotic bacteria in fermented products like yoghurt. Primarily, the probiotics must be viable and present in high count at time of consumption to achieve the desired benefits. Thus, a probiotic dairy product should contain at least 6-7 Log cfu.g ${ }^{-1}$ of viable probiotic bacteria at the time of consumption and, should be 
Table 1. Fermented dairy products, countries and microorganisms based on fermentation types (Yilmaz, 2006).

\begin{tabular}{|c|c|c|c|c|}
\hline Fermentation types & & Product names & Countries & Microorganisms \\
\hline \multirow[t]{3}{*}{$\begin{array}{c}\text { Lactic } \\
\text { Acid Fermentation }\end{array}$} & Mesophilic & $\begin{array}{c}\text { aetmjolk } \\
\text { Fimljolk } \\
\text { Lattfil } \\
\text { Ymer }\end{array}$ & $\begin{array}{c}\text { Scandinavian } \\
\text { Countries Scandinavian } \\
\text { Countries } \\
\text { Scandinavian } \\
\text { Countries Denmark }\end{array}$ & $\begin{array}{l}\text { Lactococcus lactis susp. lactis, } \\
\text { Lactococcus lactis susp. biovar } \\
\text { diacetylactis, } \\
\text { Leuconostoc mesenteroides spp. } \\
\text { Cremoris }\end{array}$ \\
\hline & Thermophilic & $\begin{array}{c}\text { Yoghurt } \\
\text { Laban ve } \\
\text { Zabadi } \\
\text { Skyr } \\
\text { Ayran } \\
\text { Mil-Mil E } \\
\text { Miru-Miru }\end{array}$ & $\begin{array}{c}\text { Various countries } \\
\text { Egypt } \\
\text { Japan } \\
\text { Japan }\end{array}$ & $\begin{array}{l}\text { L. bulgaricus, S. thermophilus } \\
\text { B. bifidum, L. bulgaricus, } \\
\text { S. thermophilus } \\
\text { L. bulgaricus, L. casei, } \\
\text { S. thermophilus } \\
\text { L. bulgaricus, } \\
\text { S. thermophilus } \\
\text { B. bifidum, B. breve, } \\
\text { L. acidophilus } \\
\text { L. casei, L. acidophilus, } \\
\text { B. breve }\end{array}$ \\
\hline & Therapeutic & $\begin{array}{c}\text { Aco-yoghurt } \\
\text { Acidophilous milk } \\
\text { AB-fermented } \\
\text { milk } \\
\text { AB-yoghurt } \\
\text { Biogarde } \\
\text { Bioghurt } \\
\text { Bifighurt } \\
\text { Yakult }\end{array}$ & $\begin{array}{c}\text { Switzerland } \\
\text { Various countries } \\
\text { Denmark } \\
\text { Denmark } \\
\text { Germany } \\
\text { Germany } \\
\text { Germany } \\
\text { Japan }\end{array}$ & $\begin{array}{l}\text { L. acidophilus, L. bulgaricus, } \\
\text { S. thermophilus } \\
\text { L. acidophilus } \\
\text { L. acidophilus, B. Bifidum } \\
\text { L. acidophilus, B. bifidum, } \\
\text { L. bulgaricus, S. thermophilus } \\
\text { L. acidophilus, B. bifidum, } \\
\text { S. thermophilus } \\
\text { S. thermophilus, } \\
\text { L. acidophilus } \\
\text { B. bifidum, S. thermophilus } \\
\text { L. casei }\end{array}$ \\
\hline $\begin{array}{l}\text { Yeast-Lactic Acid } \\
\text { Fermentation }\end{array}$ & & $\begin{array}{c}\text { Kefir } \\
\text { Koumiss } \\
\text { Acidophilous- } \\
\text { Yeast }\end{array}$ & $\begin{array}{l}\text { Russia } \\
\text { Russia } \\
\text { Russia }\end{array}$ & $\begin{array}{l}\text { Lactic Acid Bacteria, Acedic acid bacteria } \\
\text { and yeast } \\
\text { L. bulgaricus, } \\
\text { L. acidophilus, } \\
\text { Torula koumiss, Sacc. Lactis } \\
\text { L. acidophilus, lactose fermenting yeast }\end{array}$ \\
\hline $\begin{array}{l}\text { Fungus-Lactic Acid } \\
\text { Fermentation }\end{array}$ & & Viili & Finland & $\begin{array}{l}\text { Lactococcus lactis susp. lactis, } \\
\text { Lactococcus lactis susp. biovar } \\
\text { diacetylactis, } \\
\text { Leuconostoc mesenteroides subsp. } \\
\text { cremoris, Geotricum candidum }\end{array}$ \\
\hline
\end{tabular}

consumed regularly in a quantity of higher than $100 \mathrm{~g}$ per day in other words at least 9 Log cfu per day (Codex, 2003). The addition of prebiotic sources such as inulin has also been shown to improve the stability and sensory characterization of fermented milk products (Agil et al., 2013). Also, use of some supplements such as whey and whey protein concentrate has been improved probiotic viability, physico-chemical and sensorial characteristics of probiotic dairy products (Castro et al., 2013a; Castro et al., 2013b).

Selection criteria in regard to the selection of the appropriate probiotic bacteria and strains are: a) The respective bacteria have to be reported in the literature, b) There should be concrete proofs of their assistance to health c) They have to be able to colonise in gastrointestinal track and have a regulatory role in microbial balance in that area, d) In order to sustain their viability in gastrointestinal conditions, they have to be resistant to low $\mathrm{pH}$ values and bile salt e) They have to posess natural antibiotic effect, in order to prevent pathogen growth with their antimicrobial activity f) They have to be safe to consume and show no antibiotic resistance g) They have to be suitable for commercialisation (Radulović et al., 2010; Soccoll et al., 2010; Figueroa-González et al., 2011; Giraffa, 2012; Sharma et al., 2014). The possible interactions among the probiotic strains selected to manufacture of dairy product should be taken into account to select the best combination(s) and to optimize their technological performance in the process and their survival in the products during cold storaged (Saccaro et al., 2009: Casarotti et al., 2014).

Exposure to oxygen may induce a lack of functionality of probiotic dairy products because the anaerobic metabolism of probiotic bacteria compromises during storaged the maintenance of their viability to provide benefits to consumer health. The exposure to oxygen along the refrigerated storaged constitutes a technological challenge with respect to the maintenance of the probiotic dairy products, once a great part of the probiotic microorganisms grow in anaerobic systems. 
Glucose oxidase which is an enzyme produced by fungi such as Aspergillus and Penicillium can constitute a potential alternative to increase the survival of probiotic bacteria in fermented milks (Cruz et al., 2010, 2012).

\section{Popular probiotic microorganisms used in production of functional dairy products}

Probiotic microorganisms are isolated from human gastrointestinal system. Lactobacillus and Bifidobacterium species are widely known. E. faecium, E. faecalis, S. thermophilus, Lc. lactis subsp. lactis, Leuconostoc mesenteroides, Propionibacterium freudenreichii, Pediococcus acidilactici, Sporolactobacillus inulinus, E. coli, bacteria such as some Bacillus species, other lactic acid bacteria species, yeast such as Saccharomyces cerevisiae and Saccharomyces boulardii are commonly used as probiotics. (Foulquié Moreno et al., 2006; Parvez et al., 2006; Granato et al., 2010; Cutting, 2011; Nagpal et al., 2012). Interest for probiotics has arisen in recent years especially in relation to the addition of Bifidobacterium, Lactobacillus acidophilus, Lactobacillus rhamnosus, Lactobacillus casei, Lactobacillus reuteri to the fermented dairy products such as yoghurt (Guldas \& Irkin, 2010). Microorganisms that are being used to produce probiotic dairy products and to make preparations are shown in Table 2.

Lactobacillus acidophilus and Bifidobacterium animalis subsp. lactis are the lactic acid bacteria that are most frequently used as probiotics. These bacteria grow slowly in milk because they lack essential proteolytic activity and for this reason they are usually combined with Streptococcus thermophilus (Casarotti et al., 2014). Probiotic dairy products should have desired sensorial properties besides the probiotic properties. In order to achieve optimal sensorial properties, mixture of different bacteria can be used. Lactobacillus delbrueckii ssp. bulgaricus are widely used in those combinations due to their acid formation and production of aroma substances such as acetaldehyde. One of the optimal combination of those probiotic bacteria is a culture called ABT which has a combination of L. acidophilus, Bifidobacterium lactis and S. thermophilus. ABY cultures have the the same combination with ABT cultures with an addition of $L$. bulgaricus and these cultures can be used to produce yoghurt (Parvez et al., 2006; Granato et al., 2010; Casarotti et al., 2014).

\section{Lactobacillus acidophilus}

L. acidophilus is a gram positive, anaerobic or facultative anaerobic, nonmotile, catalase (-), rod-shaped bacteria. It is a homofermentative bacteria which has an optimum growth temperature of $35-38{ }^{\circ} \mathrm{C}$ and optimum $\mathrm{pH}$ interval of 5,5-6 (Tamime \& Marshall, 1997; Ozbas, 2004) It doesn’t produce ammonia from arginine but ferments amygdalin, cellobiose, fructose, glucose, galactose, mannose, trehalose, saccharose, esculin and maltose. It doesn't metabolise mannitol (Johnson et al., 1980; Ozbas, 2004). It was first isolated from children's faeces by Ernst Moro in 1900 and in 1970 it was officially acknowledged as L.acidophilus by Hansen and Mocquat. This term means lactic acid bacteria which can show growth in an acidic enviroment (Rettger et al., 1935; Ozden, 2008).

L. acidophilus has an antimicrobial effect due to the formation of organic acids (lactic acid, acetic acid, etc.), $\mathrm{H}_{2} \mathrm{O}_{2}$ and antibiotic substances (Lactocidin, Acidophilin, Acidolin, Lactocin B). As a result of $L$. acidophilus's traits, intestinal infections and disesases can be brought under control and negative effects of antibiotic treatment can be eliminated. L. acidophilus is resistant to bile acid and has a strong antibiotic effect on fecal E. coli strains and other intestinal pathogens (Uzun, 2006; Ahmed et al., 2010).

Due to originating from intestinal microbiota, L. acidophilus is usually isolated from infant's faeces. Studies has shown that ingested L.acidophilus, either through a product or pure culture, can be absorbed in intestines, can adapt and survive in gastric juice for two days and longer in bile secretion and faeces (Kilic, 2008; Ozden, 2008).

\section{Bifidobacterium ssp.}

In $8^{\text {th }}$ Bergey's Manual, Bifidobacterium ssp. was defined as an independent genus by taxonomists and named Bifidobacterium and was included in Actinomycetaceae family. Some of the defined 24 species in $9^{\text {th }}$ Bergey's Manual are B. bifidum, $B$. breve, $B$. infantis, B. thermophilum, B. adolescentis, B. longum,

Table 2. Probiotic Microorganisms used in production of fermented dairy products and preparations (Granato et al., 2010).

\begin{tabular}{ll}
\hline Lactobacillus ssp. & L. bulgaricus, L. cellebiosus, L. delbrueckii, L. acidophilus, L. reuteri, L. brevis, L. casei, Lactobacillus \\
& curvatus, L. fermentum, L. plantarum, L. johnsonii, L. rhamnosus, L. helveticus, L. salivarius, L. gasseri \\
Bifidobacterium ssp. & B. adolescentis, B. bifidum, B. breve, B. infantis, \\
& B. longum, B. thermophilum, B. lactis \\
Streptococcus/Lactococcus ssp. & L. cremoris, S. thermophilus, S. intermedius, S. lactis, \\
& L. diacetilactis \\
Bacillus ssp. & B. subtilis, B. pumilus, B. lentus, B. licheniformis, B. coagulans \\
Pediococcus ssp. & P. cerevisiae, P. acidilactici, P. pentosaceus \\
Bacteriodes ssp. & B. capillus, B. suis, B. ruminicola, B. amylophilus \\
Propionibacterium ssp. & Propionibacterium freudenreichii ssp. shermanii \\
Leuconostoc ssp. & Leu. Mesenteroides \\
Fungus & A. niger, A. oryzae \\
Yeast & S. cerevisiae, C. torulopsis \\
\hline
\end{tabular}


B. pseudolongum, B. coryneforme, B. indicum and B. dentim (Scardovi, 1986).

The use of Bifidobacterium species in fermented and cultured milk and growing knowledge of their taxonomy and ecology resulted in an increase in their popularity in the late 1970s. They grew in popularity considering low acid formation during their shelf life and higher consumption of $\mathrm{L}(+)$ lactic acid in comparison with $\mathrm{D}(-)$ lactic acid. Among the many probiotic traits that have been attributed to bifidobacteria are a) the induction of immunoglobulin production, b) improvement of food nutritional value by assimilation of substrates not metabolized by the host, c) anti-carcinogenic activity and d) folic acid synthesis (Martinez et al., 2013). Within various probiotic bacteria, Bifidobacterium lactis has been studied intensively and its beneficial roles for host health has been described. B. lactis is preferred for industrial production because of the oxygen and acid tolerance compared with other bifidobacteria species (Janer et al., 2004; Elizaquível et al., 2011; Akalin et al., 2012).

\section{Lactobacillus casei}

L. casei is in Streptobacteria subgenus and has a diameter smaller than $1.5 \mu \mathrm{m}$, has tendency to form chains and does not have flagella, it is rod shaped, nonmotile and homofermentative. By metabolising pentose, it occasionally forms L(+) lactic acid and acetic acid. $L$. casei shows rapid growth in media containing \% 4 gluconate and forms $\mathrm{CO}_{2}$. It has an optimum growth temperature of $28-32^{\circ} \mathrm{C}$ and can grow under $15^{\circ} \mathrm{C}$ and in some conditions can even show growth at $6-7^{\circ} \mathrm{C}$. L. casei can utilise sorbitol and sorbate but shows low fermentation rates with maltose and saccharose. It requires riboflavine, folic acid, Ca pantothenate and niacin for growth. It doesn't form gas and shows strong proteolytic effect after lysis (Kilic, 2008; Ernas \& Karagozlu, 2013; Wu et al., 2009).

$L$.case $i$ is a lactic acid bacteria which can be used in foods worldwide. L.casei is being used as culture or in mixtures to improve sensorial properties and in traditional dairy products such as kefir ve Laban Zeer, cheese such as provolone and parmesan, recent products such as yakult, actimel, gefilus and vifit.

\section{Lactobacillus rhamnosus}

Due to its probiotic traits, Lactobacillus rhamnosus GG or Lactobacillus GG is the most common microorganism used in dairy products marketed for infant's and children's consumption. Lactobacillus rhamnosus GG, was isolated from human faeces in 1983 and was patented in 1985. Lactobacillus rhamnosus GG is one of the most studied strains and is one of the most common bacteria that is used in probiotic preparations and foods. It has the suffix "GG" because it was discovered in Tufts University by Sherwood Gorbach and Barry Goldin. Lactobacillus rhamnosus GG was first used in the studies at 1990 and was found beneficial to children's health. Due to it's favourable impact on children's health it is widely used with products for infants and children. Some of the main traits of Lactobacillus rhamnosus GG are being indigenous to human intestinal flora, resistance to low
$\mathrm{pH}$ values and adherence to gastrointestinal track (Canbulat \& Ozcan, 2007).

\section{Enterococcus faecium/Enterococcus faecalis}

Enterococci are singular, double or short chained gram positive cocci. Streptococcus faecalis was defined by Andrewea and Horder in 1906 and Streptococcus faecium was defined by Orla-Jensen in 1919. In 1984 Schleifer and Kilpper-Balz suggested that $S$. faecalis and $S$. faecium should be distinguished from Streptococcus genus and considered in Enterococcus genus. Later on, bacteria that are studied in this genus were divided into various species such as; E. faecalis, E. faecium, E. durans, E. avium, E. casseliflavus, E. malodoratus, E. hirae, E. gallinarum, E. mundtii, E. raffinosus, E. pseudoavium, E. flavescens, E. dispar, E. sulfureus, E. saccharolyticus, E. columbae ve E. cecorum (Giraffa, 2002, 2003; Klein, 2003; Ogier \& Serror, 2008; Khan et al., 2010).

These bacteria can be found with high amounts in dairy products and other foods and although having extensive biotechnological properties such as; capability to produce bacteriocin, having probiotic traits and usage in dairy industry, there isn't a consensus on to consider them foodborne pathogens. However recent studies have shown that E. faecalis and some lactic acid bacteria species can cause clinical infections, especially infective endocarditis. E. faecalis can be found not only in human and animal faeces but also on plants and this largely reduces it's usage as a sanitation indicator (Foulquié Moreno et al., 2006; Giraffa, 2003; Kaleli \& DurluOzkaya, 2000; Bhardwaj et al., 2008).

Among Enterococcus genus, Enterococcus faecium and Enterococcus faecalis are stated to have probiotic traits. Enterococcus faecium's usage on diarrhea treatment is considered to be an alternative for antibiotic use. The probiotic effect of Enterococcus faecium on humans arise out of reducing the absorbtion of cholesterol from digestive system (Erginkaya et al., 2007).

\section{Lactobacillus gasseri}

Lactobacillus gasseri is a rod shaped, non spore forming lactic acid bacteria. This bacteria is a prolific autochthonous microorganism that colonizes the GIT, oral cavity, and vagina in humans. Lactobacillus gasseri is classified as a group B acidophilus complex microorganism, and can be differentiated from group A members by the way of genetic determination and the apparent absence of major surface-layer (S-layer) proteins. The niche-related phenotypes involved incolonization of the human mucosa, including the oral cavity, GIT, and vagina are exhibited by LAB such as L. gasseri and may contribute to or potentiate probiotic activity (Selle \& Klaenhammer, 2013). L. gasseri shows to be beneficiary to gastrointestinal system and is stated to have the capability to reduce fecal mutagenic enzyms due to it's probiotic acitivity. It has the ability to adhere to intestines and has a role in bacteriocin formation and macrophage stimulation. In the view of it's probiotic traits, it can be used in the production of fermented diary products and in commercial preparations (Uzuner, 2012). 


\section{Streptococcus thermophilus}

S. thermophilus is a gram positive, circular or elliptical bacteria which has a diameter of 0,7 - 0,9 micron. Morphology of bacteria depends on the genus, enviroment and growth temperatures. For instance, they have short chains at $45^{\circ} \mathrm{C}$, are diplococcus at $30^{\circ} \mathrm{C}$ but have long chains in cultures that have high acidity. Bacteria in question show symbiotic relationship with L. bulgaricus at yoghurt production. At first S. thermophilus shows activity in the milk fermented to produce yoghurt, and slightly increases the acidity of the media and consumes oxygen. L. bulgaricus starts to grow rapidly in this medium and forms valine which is a necessity for $S$. thermophilus's growth (Yaygin \& Kilic, 1991; Iyer et al., 2010). Besides yoghurt production, they are present in various starter cultures that are used to produce fermented dairy products and cheese (Iyer et al., 2010).

\section{Propionibacterium species}

In 1906, Freudenreich and Orla-Jensen isolated bacteria from Emmantel cheese and named them Bacterium acidipropionici and Bacillus acidi-propionici. These organisms are defined based on their capability to form propionic acid. The class Propionibacterium was first introduced by Orla-Jensen in 1909. Classical PAB, also known as "dairy-propionibacteria" are usually present in raw milk, butter and are known for their significant role in maturation process of Swiss type cheeses. Because of their presence in natural flora and starter culture, $\mathrm{PAB}$ have a signicant role in nonconventional cheese production. Further, by forming propionic acid and acetic acid $\mathrm{PAB}$ contributes to the sensorial properties of these products. In milk and other dairy products, Propionibacterium ferudenreichii, Propionibacterium jensenii and Propionibacterium acidipropionici are present prior to the other species of this genus (Cousin et al., 2011).

\section{Saccharomyces cerevisiae boulardii}

Saccharomyces boulardii was discovered by French researcher Boulard in 1923 and is a Gram positive yeast which is a member of Saccharomycetaceae family. It is elliptical or spherical shaped and has a size of $4-8 \mu \mathrm{m}$. It forms ascospore and grows in standard yeast mediums with and optimal growth temperature of $37^{\circ} \mathrm{C}$ and has the capability to assimilate and ferment carbohydrates and can prevent microbial pathogen growth. Saccharomyces boulardii shows no pathogenic properties and was isolated from a tropical fruit (lychee fruit) which grows in Southeast Asia and was used for the treatment of diarrhea. In 1962, lyophilised commercial preparation of S. boulardii was introduced and notably in France, used as a cure for diarrhea ever since. Diverse arguments are ongoing about it's being a subspecies of Saccharomyces cerevisiae (McCullough et al., 1998; Ertor, 2003; Gultekin, 2004; Czerucka et al., 2007). Lyophilised S. boulardii is being used clinically in Europe, Asia, Africa and South America. Preclinical and experimental studies has shown that Saccharomycess boulardii has anti inflammatory, antimicrobial, enzymatic, metabolic and antitoxic activities (Ertor, 2003; Billoo et al., 2006; Szajewska, 2012).

\section{Probiotic dairy drinks}

\subsection{Acidophilus milk}

Acidophilus milk is a type of fermented dairy product and L.acidophilus is used as culture. In the fermented Acidophilus milk production, milk is heat processed at $95^{\circ} \mathrm{C}$ and goes through homogenisation. Later, it is cooled to $37^{\circ} \mathrm{C}$ and inoculated with $2-5 \%$ commercial L.acidophilus pure culture and left for incubation for 12-24 hours. Following incubation, milk is cooled to $5^{\circ} \mathrm{C}$ and kept under cold conditions. However, in some Acidophilus milk productions, milk goes through the heat process at above $120^{\circ} \mathrm{C}$ and then cooled and inoculated with 2-5\% commercial L.acidophilus pure culture. The following process is described above. The purpose of using high temperatures is to eliminate competition and better L.acidophilus growth. In the production of unfermented Acidophilus milk, commercial L. acidophilus pure culture is inoculated to cold milk $\left(5-7^{\circ} \mathrm{C}\right)$ and milk is kept under cold conditions (Kurmann et al., 1992; Ozden, 2008; Shiby \& Mishra, 2013).

Bacteria populate in intestinal system and prevent the activity of harmful gas forming microorganisms. It is beneficial to people with diarrhea and intestinal gas problems (Kilic, 2008). Akpinar (2008) determined that with the use of several aroma substances, improvement in sensorial properties of acidophilus milk is obtainable and reported that strawberry aroma in particular, arouses interest.

\subsection{Bifidus milk and Acidophilus-Bifidus milk}

Bifidus milk is the first infant product produced with Bifidobacteria and was first produced by Mayer in 1948 at Germany. Today, Bifidobacterium bifidum and Bifidobacterium longum culture is inoculated with a $10 \%$ ratio to milk cooled to the fermentation temperature. Ready to use product has a 4.3-4.7 $\mathrm{pH}$ value and contains 10-100 million bifidobacteria in 1 gram (Kurmann et al., 1992). Bifidus milk is easy to digest and is still used for the treatment of gastrointestinal and liver diseases and for constipation (Ozden, 2008). It is produced in Germany and has an acidic and spicy aroma which differs it in taste from other products.

It is produced by using Bifidobacterium bifidum and Bifidobacterium longum isolated from healthy humans faeces. They form $\mathrm{L}(+)$ lactic acid. Milk is standardised and homogenised and kept at $80-120{ }^{\circ} \mathrm{C}$ for 5-10 minutes. Then, $10 \%$ bifidobacteria culture is inoculated to milk and the milk is left for incubation at $37^{\circ} \mathrm{C}$ until coagulation. Once it reaches to a $\mathrm{pH}$ value of 4.3-4.7, incubation is ended. It is packed and kept in cold conditions. The final product contains $10^{8}-10^{9}$ $\mathrm{cfu} / \mathrm{ml}$ bacteria. Acidophilus-Bifidus milk, also known as $\mathrm{AB}$ culture, is a fermented dairy product which is produced with L. acidophilus and Bifidobacterium ssp. It contains high levels of viable bacteria with 1:1 bacteria ratio (Kurmann et al., 1992; Ozden, 2008). 


\subsection{Mil-Mil}

Mil-Mil is a Japan originated fermented dairy product. A mixture of Bifidobacterium bifidum, Bifidobacterium breve and $L b$. acidophilus cultures is used in the production. It was developed by Yakult Honsha company in Japan. The product is enriched with smal quantities of glucose and fructose and carrot juice. Hence, it is rich in provitamin A. Mil-Mil can also be consumed as soup (Kurmann et al., 1992).

\subsection{Yakult}

Yakult is a probiotic dairy product which is produced with L. casei Shirota strain. L. casei Shirota is resistant to gastric and duedonal acid, can populate and form antimicrobial substances in small intestine and has the ability to improve the activity and quantity of macrophages. L. casei Shirota strain was discovered by Japanese researcher Dr. Shirota in 1935. It is used in commercial products by Yakult Honsha company since 1955. It is proven to be advantageous for health and is on the market in 15 different countries including European countries. Yakult is yet to be on the market in our country. Attention should be paid to yakult and similar products and they should be introduced to the consumers (Kucukcetin \& Yaygin, 2000; Gokce \& Ustun, 2001).

\subsection{Kefir}

Kefir is a naturally carbonated, slightly acidic fermented dairy product which is produced with kefir grains and contains complex and specific mixture of yeast and bacteria in a polysaccharide matrix. In Turkish, kefir is defined as "good food". It is also known as Kephir, Kefyr, Kefer, Kiaphur, Knapon, Kepi and Kipi (Stepaniak \& Fetlinski, 2002; Sarkar, 2007a; Ahmed et al., 2013).

Kefir is a North Caucasia originated fermented dairy product which is considered to be important for human diet in many regions such as Southwest Asia, East and North Europe, North America, Japan, Middle East and Russia. Kefir is recommended for six months old and older infants and due to it's Bifidobacterium bifidum content, Bifidokefir has been found more effective on the treatment of infantile intestinal diseases than regular kefir. Health benefits of kefir have been pointed out by numerous researchers (Stepaniak \& Fetlinski, 2002; Sarkar, 2007a, b; Guzel-Seydim et al., 2011; Ahmed et al., 2013).

Kefir is produced using kefir grains and full or non fat milk and is a fermented dairy product consists of gel like colonies of casein and microorganism (bacteria and yeast) in a simbiotic relationship. There are several ways to produce kefir. Traditional and industrial processes are commonly used and food scientists are trying to develop new methods to obtain similar kefir produced with traditional ways. Consumers prefer kefir produced with kefir grains to kefir produced with starter culture. In comparison with the traditional kefir, cultured kefir is lower in acidity and shows less synaeresis. Kefir can be produced using cow, sheep, goat, soy, rice and coconut milk. Pastorized, raw, semi skimmed, skimmed, non fat or full fat milk can be used in production. In the production of kefir with the use of cow, sheep and goat milk, lactic acid and alcohol fermentations take place simultaneously. It is stated that as a result of this simultaneity, besides being easy to digest, refreshing and appetising, it is also suitable for some diseases and has a foamy quality due to it's $\mathrm{CO}_{2}$ content (Karagozlu \& Kavas, 2000; Otles \& Cagindi, 2003; Ozden, 2008; Guzel-Seydim et al., 2011; Ahmed et al., 2013).

\subsection{Koumiss-Kumiss}

Koumiss is defined as a national beverage produced form mare milk. In Kazakh it is known as Q1mız(is). Different names of koumiss in other languages are: koumis (French), (German), kumyss, kumys, кумыс (Russsian) (Üstün, 2009; Dictionary. com, 2013).

Koumiss is produced with traditional methods in houses and small scaled productions while it is produced with industrial methods in sanitariums and large scaled productions. It contains $2 \%$ alcohol, $0.5-1.5 \%$ lactic acid, 2-4\% milk sugar and $2 \%$ fat and it tastes like sour ayran. Koumiss is recommended for the treatment of tuberculosis, asthma, pneumonitis, cardiovascular diseases and gynaecological diseases. It is also suitable for weight gain and increasing robustness and energy (Yaygin, 1992; Kinik et al., 2000; Karagozlu \& Kavas, 2000; Ozden, 2008; Ustun, 2009; Dictionary.com, 2013).

\subsection{Acidophilin}

Acidophilin is a product, produced from cow milk with a process involves the use of a high quality starter culture and it tastes rather acidic. The culture primarily contains $L b$. acidophilus. In addition to $L b$. acidophilus, it contains Lc. lactis ssp. lactis or Lb. delbrueckii ssp. bulgaricus. In some cases, kefir culture may be inoculated to the culture with a 1:1:1: ratio (Kurmann et al., 1992; Tamime \& Marshall, 1997).

Prior to the inoculation at $18-25^{\circ} \mathrm{C}$, the homogenised milk is heated up to $90-92^{\circ} \mathrm{C}$ for at least 3 minutes. Milk is left for incubation until it reaches $0.67-0.72 \%$ titrable acidity. It is cooled, packed and kept in cold chain. Acidity of Acidofilin is around $0.67-1.08 \%$ and the final product contains $97 \%$ L. lactis ssp. lactis, $2 \%$ L. acidophilus and $1 \%$ yeast. It has a lower antimicrobial acitivity than acidophilus milk (Kurmann et al., 1992; Tamime \& Marshall, 1997).

\subsection{Miru-Miru}

Miru-miru is a dairy product which is produced with a combination of L. casei, L. acidophilus and Bifidobacterium breve and is produced in Japan (Kilic, 2008).

\section{Conclusion}

Fermented dairy products are crucial to the human diet. Today, due to the increasing demand on safe and functional foods, consumption of new and enriched foods has shown growth to higher rates. In our country, along with high consumption rates of ayran, tendency to consume kefir and other probiotic beverages increases with each passing day. It is quite apparent that with the release of new probiotic and fermented dairy beverages to the market, there will be growing demand on these products. Hence, release of new products to the market and further studies about their functional traits are needed. 


\section{References}

Agil, R., Gaget, A., Gliwa, J., Avis, T. J., Willmore, W. G., \& Hosseinian, F. (2013). Lentils enhance probiotic growth in yogurt and provide added benefit of antioxidant protection. LWT - Food Science and Technology, 50(1), 45-49. http://dx.doi.org/10.1016/j. lwt.2012.07.032

Ahmed, Z., Wang, Y., Ahmad, A., Tariq Khan, S., Nisa, M., Ahmad, H., \& Afreen, A. (2013). Kefir and health: a contemporary perspective. Critical Reviews in Food Science and Nutrition, 53(5), 422-434. PMid:23391011. http://dx.doi.org/10.1080/10408398.2010.540360

Ahmed, Z., Wang, Y., Cheng, Q., \& Imran, M. (2010). Lactobacillus acidophilus bacteriocin, from production to their application: an overview. African Journal of Biotechnology, 9(20), 2843-2850.

Akalin, A. S., Unal, G., Dinkci, N., \& Hayaloglu, A. A. (2012). Microstructural, textural, and sensory characteristics of probiotic yogurts fortified with sodium calcium caseinate or whey protein concentrate. Journal of Dairy Science, 95(7), 3617-3628. PMid:22720919. http://dx.doi.org/10.3168/jds.2011-5297

Akpinar, A. (2008). Acidophilus milk properties with to produce added different flavour components (Master's thesis). Ege University, Bornova.

Bhardwaj, A., Malik, R. K., \& Chauhan P. (2008). Functional and safety aspects of enterococci in dairy foods. Indian Journal of Microbiology, 48(3), 317-325. PMid:23100728 PMCid:PMC3476767. http://dx.doi.org/10.1007/s12088-008-0041-2

Billoo, A. G., Memon, M. A., Khaskheli, S. A., Murtaza, G., Iqbal, K., Saeed Shekhani, M., \& Iddiqi, A. Q. (2006). Role of a probiotic (Saccharomyces boulardii) in management and prevention diarrhoea. World Journal of Gastrology, 12(28), 4557-4560.

Canbulat, Z., \& Ozcan, T. (2007). The health impact of using Lactobacillus rhamnosus GG in infant formulas and children's dietary supplements. Journal of Agricultural Faculty of Uludag University, 21(1), 69-79.

Casarotti, S. N., Monteiro, D. A., Moretti, M. M. S., \& Penna, A. L. B. (2014). Influence of the combination of probiotic cultures during fermentation and storage of fermented milk. Food Research International, 59, 67-75. http://dx.doi.org/10.1016/j. foodres.2014.01.068

Castro, W. F., Cruz, A. G., Bisinotto, M. S., Guerreiro, L. M., Faria, J. A., Bolini, H. M., Cunha R. L., \& Deliza, R. (2013a). Development of probiotic dairy beverages: rheological properties and application of mathematical models in sensory evaluation. Journal of Dairy Science, 96(1), 16-25. PMid:23102956. http://dx.doi.org/10.3168/ jds.2012-5590

Castro, W. F., Cruz, A. G., Rodrigues, D., Ghiselli, G., Oliveira, C. A., Faria, J. A., \& Godoy, H. T. (2013b). Short communication: effects of different whey concentrations on physicochemical characteristics and viable counts of starter bacteria in dairy beverage supplemented with probiotics. Journal of Dairy Science, 96(1), 96100. PMid:23182354. http://dx.doi.org/10.3168/jds.2012-5576

Codex. (2003). Codex Stan 243-2003: Codex standard for fermented milks. Rome: Codex Alimentarius Commission. Retrieved from http://www.codexalimentarius.net/download/standards/400/ CXS_243e.pdf

Cousin, F. J., Mater, D. D. G., Foligne, B., \& Jan, G. (2011). Dairy propionibacteria as human probiotics: a review of recent evidence. Dairy Science and Technology, 91(1), 1-26.

Cruz, A. G., Castro, W. F., Faria, J. A., Lollo, P. C., Amaya-Farfán, J., Freitas, M. Q., Rodrigues, D., Oliveira, C. A., \& Godoy, H. T. (2010). Probiotic yogurts manufactured with increased glucose oxidase levels: postacidification, proteolytic patterns, survival of probiotic microorganisms, production of organic acid and aroma compounds. Journal of Dairy Science, 95(5), 2261 -2269. PMid:22541455. http:// dx.doi.org/10.3168/jds.2011-4582

Cruz, A. G., Castro, W. F., Faria, J. A. F., Bogusz Jr., S., Granato, D., Celeguini, R. M. S., Lima-Pallone, J., \& Godoy, H. T. (2012). Glucose oxidase: a potential option to decrease the oxidative stress in stirred probiotic yogurt. LWT - Food Science and Technology, 47(2), 512515. http://dx.doi.org/10.1016/j.lwt.2012.01.037

Cruz, A. G., Faria, J. A., Walter, E. H., Andrade, R. R., Cavalcanti, R. N., Oliveira, C. A., \& Granato, D. (2010). Processing optimization of probiotic yogurt containing glucose oxidase using response surface methodology. Journal of Dairy Science, 93(11), 5059-5068. PMid:20965320. http://dx.doi.org/10.3168/jds.2010-3336

Cutting, S. M. (2011). Bacillus probiotics. Food Microbiology, 28(2), 214220. PMid:21315976. http://dx.doi.org/10.1016/j.fm.2010.03.007

Czerucka, D., Piche, T., \& Rampal, P. (2007). Review article: yeast as probiotics-Saccharomyces boulardii. Alimentary Pharmacology and Therapeutics, 26(6), 767-778. PMid:17767461. http://dx.doi. org/10.1111/j.1365-2036.2007.03442.x

Dictionary.com. (2013). Kumiss. Oakland: Dictionary.com. Retrieved from http://dictionary.reference.com/browse/kumiss

Divya, J. B., Varsha, K. K., Nampoothiri, K. M., Ismail, B., \& Pandey, A. (2012). Probiotic fermented foods for health benefits. Engineering in Life Science, 12(4), 377-390. http://dx.doi.org/10.1002/ elsc.201100179

Ejtahed, H. S., Mohtadi-Nia, J., Homayouni-Rad, A., Niafar, M., Asghari-Jafarabadi, M., Mofid, V., \& Akbarian-Moghari, A. (2011). Effect of probiotic yogurt containing Lactobacillus acidophilus and Bifidobacterium lactis on lipid profile in individuals with type 2 diabetes mellitus. Journal of Dairy Science, 94(7), 3288-3294. PMid:21700013. http://dx.doi.org/10.3168/jds.2010-4128

Elizaquível, P., Sánchez, G., Salvador, A., Fiszman, S., Dueñas, M. T., López, P., Fernández de Palencia, P., \& Aznar, R. (2011). Evaluation of yogurt and various beverages as carriers of lactic acid bacteria producing 2-branched $(1,3)-\beta$-D-glucan. Journal of Dairy Science, 94(7), 3271-3278. PMid:21700011. http://dx.doi. org/10.3168/jds.2010-4026

Erginkaya, Z., Yurdakul, N. E., \& Karakas, A. (2007). The properties of Enterococcus faecium and Enterococcus faecalis as a starter and probiotiv cultures. Journal of Food, 32(3), 137-142, 2007.

Ernas, M., \& Karagozlu, C. (2003). Probiotic properties of Lactobacillus casei. Journal of Food, 3, 64 -69.

Ertor, O. (2003). Saccharomyces boulardii: infeksiyöz ishal tedavisinde yeni bir seçenek mi? Klimik Dergisi, 16, 3-7.

Figueroa-González, I., Quijano, G., Ramírez, G., \& Cruz-Guerrero, A. (2011). Probiotics and prebiotics: perspectives and challenges. Journal of Science of Food and Agriculture, 91(8), 1341-1348. PMid:21445871. http://dx.doi.org/10.1002/jsfa.4367

Foulquié Moreno, M. R., Sarantinopoulos, P., Tsakalidou, E., \& De Vuyst, L. (2006). The role and application of enterococci in food and health. International Journal of Food Microbiology, 106, 1-24. PMid:16216368. http://dx.doi.org/10.1016/j.ijfoodmicro.2005.06.026

Gibson, G. R., \& Fuller, R. (2000). Aspects of in vitro and in vivo research approaches directed toward identifying probiotics and probiotics for human use. Journal of Nutrition, 130(2), 391-395.

Giraffa, G. (2002). Enterococci from foods. FEMS Microbiology Reviews, 26(2), 163-171. PMid:12069881. http://dx.doi. org/10.1111/j.1574-6976.2002.tb00608.x 
Giraffa, G. (2003). Functionality of enterococci in dairyproducts. International Journal of Food Microbiology, 88(2-3), 215-222. http:// dx.doi.org/10.1016/S0168-1605(03)00183-1

Giraffa, G. (2012). Selection and design of lactic acid bacteria probiotic cultures. Engineering in Life Science, 12(4), 391-398. http://dx.doi. org/10.1002/elsc.201100118

Gobbetti, M., di Cagno, R., \& de Angelis, M. (2010). Functional microorganisms for functional food quality. Critical Reviews in Food Science and Nutrition, 50(8), 716-727. PMid:20830633. http:// dx.doi.org/10.1080/10408398.2010.499770

Gokce, R., \& Ustun, O. (2001). Yurtdışında üretilen fermente süt içecekleri. Gıda Mühendisliği Dergisi, 10, 24-29.

Gomes, A. A., Braga, S. P., Cruz, A. G., Cadena, R. S., Lollo, P. C., Carvalho, C., Amaya-Farfán, J., Faria, J. A., \& Bolini, H. M. (2011). Effect of the inoculation level of Lactobacillus acidophilus in probiotic cheese on the physicochemical features and sensory performance compared with commercial cheeses. Journal of Dairy Science, 94(10), 4777-4786. PMid:21943729. http://dx.doi. org/10.3168/jds.2011-4175

Granato, D., Branco, G. F., Cruz, G., Faria, J. F., \& Shah, N. P. (2010). Probiotic dairy products as functional foods. Comprehensive Reviews in Food Science and Food Safety, 9(5), 455-470. http://dx.doi. org/10.1111/j.1541-4337.2010.00120.x

Guldas, M., \& Irkin, R. (2010). Influence of Spirulina platensis powder on the microflora of yoghurt and acidophilus milk. Mljekarstvo, 60(4), 237-243.

Gultekin, M. (2004). Probiotics. Journal of ANKEM, 18(2), 287-289.

Guzel-Seydim, Z. B., Kok-Tas, T., Greene, A. K., \& Seydim, A. C. (2011). Review: functional properties of kefir. Critical Reviews in Food Science and Nutrition, 51(3), 261-268. PMid:21390946. http:// dx.doi.org/10.1080/10408390903579029

Hugenholtz, J. (2013). Traditional biotechnology for new foods and beverages. Current Opinion in Biotechnology, 24(2), 155-159. PMid:23395405. http://dx.doi.org/10.1016/j.copbio.2013.01.001

Iyer, R., Tomar, S. K., Maheswari, T. U., \& Singh, R. (2010). Streptococcus thermophilus strains: Multifunctional lactic acid bacteria. International Dairy Journal, 20, 133-141. http://dx.doi. org/10.1016/j.idairyj.2009.10.005

Janer, C., Peláez, C., \& Requena, T. (2004). Caseinomacropeptide and whey protein concentrate enhance Bifidobacterium lactis growth in milk. Food Chemistry, 86(2), 263-267. http://dx.doi.org/10.1016/j. foodchem.2003.09.034

Johnson, J. L., Phelps, C. F., Cummins, C. S., London, J., \& Gasser, F. (1980). Taxonomy of the Lacto bacillus acidophilus Group. International Journal of Systematic Bacteriology, 30(1), 53-68. http:// dx.doi.org/10.1099/00207713-30-1-53

Kaleli, D., \& Durlu-Ozkaya, F. (2000). Food microbiology and practices. Ankara: Ankara University. PMid:10725581.

Kanmani, P., Kumar, R. S., Yuvaraj, N., Paari, K. A., Pattukumar, V., \& Arul, V. (2013). probiotics and its functionally valuable products: a review. Critical Reviews in Food Science and Nutrition, 53(6), 641658. PMid:23627505. http://dx.doi.org/10.1080/10408398.2011. 553752

Karagozlu, C., \& Kavas, G. (2000). Alkollü fermente süt içecekleri: kefir ve kimizin özellikleri ile insan beslenmesindeki önemi. Dunya Food, 6(7), 86-93.

Karimi, R., Mortazavian, A. M., \& Karami, M. (2012). Incorporation of Lactobacillus casei in Iranian ultrafiltered Feta cheese made by partial replacement of $\mathrm{NaCl}$ with $\mathrm{KCl}$. Journal of Dairy
Science, 95(8), 4209-4222. PMid:22818434. http://dx.doi. org/10.3168/jds.2011-4872

Khan, H., Flint, S., \& Yu, P. L. (2010). Enterocins in food preservation. International Journal of Food Microbiology, 141(12), 1-10. PMid:20399522. http://dx.doi.org/10.1016/j. ijfoodmicro.2010.03.005

Kilic, S. (2008). Lactic acid bacteria in dairy industry. Bornova: Ege University Press. Agriculture Faculty Publications 542.

Kinik, O., Akalin, S., \& Gonc, S. (2000). A research on Koumiss production and its properties. Journal of Food, 25(5), 379-384.

Klein, G. (2003). Taxonomy, ecology and antibiotic resistance of enterococci from food and the gastro-intestinal tract. International Journal of Food Microbiology, 88(2-3), 123-131. http://dx.doi. org/10.1016/S0168-1605(03)00175-2

Kucukcetin, A., \& Yaygin, H. (2000). Yakult and their properties. Dunya Food, 7, 84-85.

Kurmann, J. A., Rasic, J. L. J., \& Kroger, M. (1992). Encyclopedia of fermented fresh milk products. New York: Van Nostrand Reinhold.

Lollo, P. C. B., Moura, C. S., Morato, P. N., Cruz, A. G., Castro, W. F., Betim, C. B., Nisishima, L., Faria, J. A. F., Maróstica Jr., M., Fernandes, C. O., \& Amaya-Farfan, J. (2013). Probiotic yogurt offers higher immune-protection than probiotic whey beverage. Food Research International, 54(1), 118-124. http://dx.doi.org/10.1016/j. foodres.2013.06.003

Martinez, F. A. C., Balciunas, E. M., Converti, A., Cotter, P. D., \& Souza Oliveira, R. P. D. (2013). Bacteriocin production by Bifidobacterium spp.: a review. Biotechnology Advances, 31(4), 482-488. PMid:23384878. http://dx.doi.org/10.1016/j.biotechadv.2013.01.010

McCullough, M. J., Clemons, K. V., McCusker, J. H., \& Stevens D. A. (1998). Species identification and virulence attributes of Saccharomyces boulardii (nom. inval.). Journal of Clinical Microbiology, 36(9), 2613-2617. PMid:9705402 PMCid:PMC105172.

Minervini, F., Siragusa, S., Faccia, M., Dal Bello, F., Gobbetti, M., \& De Angelis, M. (2012). Manufacture of Fior di Latte cheese by incorporation of probiotic lactobacilli. Journal of Dairy Science, 95(2), 508-520. PMid:22281315. http://dx.doi.org/10.3168/ jds.2011-4150

Moayednia, N., Ehsani, M. R., Emamdjomeh, Z., \& Mazaheri, A. F. (1999). Effect of refrigerated storage time on the viability of probiotic bacteria in fermented probiotic milk drinks. International Journal of Dairy Technology, 62(2), 204-208. http://dx.doi.org/10.1111/j.14710307.2009.00473.x

Nagpal, R., Kumar, A., Kumar, M., Behare, P. V., Jain, S., \& Yadav, H. (2012). Probiotics, their health benefits and applications for developinghealthier foods: a review. FEMS Microbiology Letters, 334(1), 1-15. PMid:22568660. http://dx.doi.org/10.1111/ j.1574-6968.2012.02593.x

Nilsson, L. E., Lyckand, S., \& Tamime, A. Y. (2006). Production of drinking products. In A. Y. Tamime (Ed.), Fermented milks. Oxford: Blackwell Science. http://dx.doi.org/10.1002/9780470995501.ch5

Ogier, J. C., \& Serror, P. (2008). Safety assessment of dairy microorganisms: the Enterococcus genus. International Journal of Food Microbiology, 126(3), 291-301. PMid:17889954. http://dx.doi. org/10.1016/j.ijfoodmicro.2007.08.017

Otles, S., \& Cagindi, O. (2003). Kefir: a probiotic dairy composition, nutritional and therapeutic aspects. Pakistan Journal of Nutrition, 2(2), 54-59. http://dx.doi.org/10.3923/pjn.2003.54.59

Ozbas, Z. Y. (2004). Bifidobacteria and Lactobacillus: behaviour, using for dietary purposes, beneficial effects and applications of products. Journal of Food, 18(4), 247-251. 
Ozden, A. (2008). Other fermented dairy products: bioyogurt-probiotic yogurt. Guncel Gastroenteroloji, 12(3), 169-181.

Ozer, B. H., \& Kirmaci, H. A. (2010). Functional milks and dairy beverages. International Journal of Dairy Technology, 63(1), 1-15. http://dx.doi.org/10.1111/j.1471-0307.2009.00547.x

Parvez, S., Malik, K. A., Kang, A., \& Kim, H. Y. (2006). Probiotics and their fermented food products are beneficial for health. Journal of Applied Microbiology, 100(6), 1171-1185. PMid:16696665. http:// dx.doi.org/10.1111/j.1365-2672.2006.02963.x

Radulović, Z., Petrović, T., Nedović, V., Dimitrijević, S., Mirković, N., Petrušić, M., \& Paunović, D. (2010). Characterization of autochthonous Lactobacillus paracasei strains on potential probiotic ability. Mljekarstvo, 60(2), 86-93.

Rettger, L. F., Levy, M. N., Weinstein, L., \& Weiss, J. E. (1935). Lactobacillus acidophilus and its therapeutic application. London: Yale University Press.

Saccaro, D. M., Tamime, A. Y., Pilleggi, A. N. A .L. O. P. S., \& Oliveira, M. N. (2009). The viability of three probiotic organisms grown with yoghurt starter cultures during storage for 21 days at $4{ }^{\circ} \mathrm{C}$. International Journal of Dairy Technology, 62(3), 397-404. http:// dx.doi.org/10.1111/j.1471-0307.2009.00497.x

Salminen, S., Ouwehand, A., Benno, Y., \& Lee, Y. K. (1999). Probiotics: how should theybe defined? Trends in Food Science and Technology, 10(3), 107-110. http://dx.doi.org/10.1016/S09242244(99)00027-8

Sarkar, S. (2007a). Biotechnological innovations in kefir production: a review. British Food Journal, 110(3), 283-295. http://dx.doi. org/10.1108/00070700810858691

Sarkar, S. (2007b). Potential of kefir as a dietetic beverage: a review. British Food Journal, 109(4), 280-290. http://dx.doi. org/10.1108/00070700710736534

Scardovi, V. (1986). Genus Bifidobacterium Orla-Jensen 1974, 472AL. In P. H. A. Sneath, N. S. Mair, M. E. Sharpe \& J. G. Holt (Eds.), Bergey's manual of systematic bacteriology (Vol. 1, pp. 1418-1434). Baltimore: Williams \& Wilkins.

Selle, K., \& Klaenhammer, T. R. (2013). Genomic and phenotypic evidence for probiotic infuences of Lactobacillus gasseri on human health. FEMS Microbiology Reviews, 37(6), 915-935. PMid:23488471.

Shah, N. P. (2001). Functional foods from probiotics and prebiotics. Food Technology, 55(11), 46-53.

Sharma, P., Tomar, S. K., Goswami, P., Sangwan, V., \& Singh, R. (2014). Antibiotic resistance among commercially available probiotics. Food Research International, 57, 176-195. http://dx.doi.org/10.1016/j. foodres.2014.01.025

Shiby, V. K., \& Mishra, H. N. (2013). Fermented milks and milk products as functional foods: a review. Critical Reviews in Food Science and Nutrition, 53(5), 482-496. PMid:23391015. http://dx.doi. org/10.1080/10408398.2010.547398
Soccoll, C. R., Souza Vandenberghe, L. P., Spier, M. R., Pedroni Medeiros, A. B., Yamaguishi, C. T., Lindner, J. D., Pandey, A., \& Thomaz-Soccol, V. (2010). The potential of probiotics: a review. Food Technology and Biotechnology, 48(4), 413-434.

Stepaniak, I., \& Fetlinski, A. (2002). Kefir. In H. Roginski (Ed.), Encyclopedia of Dairy Science (pp. 1049-1054). London: Elsevier Science.

Šušković, J., Kos, B., Beganović, J., Pavunc, A. L., Habjanić, K., \& Matošić, S. (2010). Antimicrobial activity: the most important property of probiotic and starter lactic acid bacteria. Food Technology and Biotechnology, 48(3), 296-307.

Szajewska, H. (2012). An update on Saccharomyces boulardii. Przeglad Gastroentorogiczny, 7(6), 351-358.

Tamime, A. Y., \& Robinson, R. K. (1999). Yoghurt: science and technology (2nd ed.). Boca Raton: CRC Press.

Tamime, A. Y., \& Marshall, V. M. E. (1997). Microbiology and technology of fermented milks. In B. A. Law (Ed.), Microbiology and biochemistry of cheese and fermented milk (2nd ed., pp. 57152). London: Blackie Academic \& Professional. http://dx.doi. org/10.1007/978-1-4613-1121-8_3

Üstün, C. (2009). An ancient turkish beverage: Kimiz (Koumiss). Türklük Bilimi Araştırmaları, (26), 247-255.

Uzun, Y. S. (2006). A study on viability of Lactobacillus acidophilus La-5 and Bifidobacterium bifidum BB-12 against scalding and dry salting during kasar cheesemaking (Master's thesis). Harran University, Şanliurfa.

Uzuner, E. (2012). Use of rice milk in probiotic yogurt production. Bornova: Ege University. Scientific Research Projects 2009-ZRF009.

Vaughan, E. E., \& Mollet, B. (1999). Probiotics in the new millennium. Nahrung, 43(3), 148-153. http://dx.doi.org/10.1002/(SICI)15213803(19990601)43:3<148::AID-FOOD148>3.0.CO;2-Z

Wu, R., Wang, W., Yu, D., Zhang, W., Li, Y., Sun, Z., Wu, J., Meng, H., \& Zhang, H. (2009). Proteomics analysis of Lactobacillus casei Zhang, a new probiotic bacterium isolated from traditional home-made Koumiss in Inner Mongolia of China. Molecular and Cellular Protecteomics, 8(10), 2321-2338. PMid:19508964 PMCid:PMC2758759. http://dx.doi.org/10.1074/mcp.M800483MCP200

Yaygin, H. (1992). Koumiss and its properties. Antalya: Yeni Press.

Yaygin, H., \& Kilic, S. (1991). Pure culture in dairy industry. İzmir: Altındag Press.

Yilmaz, L. (2006). The use of different probiotic culture combinations in production of yoghurt-like fermented dairy products (Doctoral thesis). Uludag University, Bursa.

Ziemer, C. J., \& Gibson, G. R. (1998). An overview of probiotics, prebiotics and synbiotcs in the functional food concept: perspectives and future strategies. International Dairy Journal, 8, 473-479. http:// dx.doi.org/10.1016/S0958-6946(98)00071-5 